This item was submitted to Loughborough's Research Repository by the author.

Items in Figshare are protected by copyright, with all rights reserved, unless otherwise indicated.

\title{
Venture capital in malaysia: the role of government
}

PLEASE CITE THE PUBLISHED VERSION

http://dx.doi.org/10.1111/j.1467-7679.1995.tb00099.x

\section{PUBLISHER}

Blackwell Publishing (@ Overseas Development Institute)

VERSION

AM (Accepted Manuscript)

LICENCE

CC BY-NC-ND 4.0

REPOSITORY RECORD

Boocock, Grahame. 2019. "Venture Capital in Malaysia: The Role of Government”. figshare. https://hdl.handle.net/2134/7668. 
This item was submitted to Loughborough's Institutional Repository (https://dspace.lboro.ac.uk/) by the author and is made available under the following Creative Commons Licence conditions.

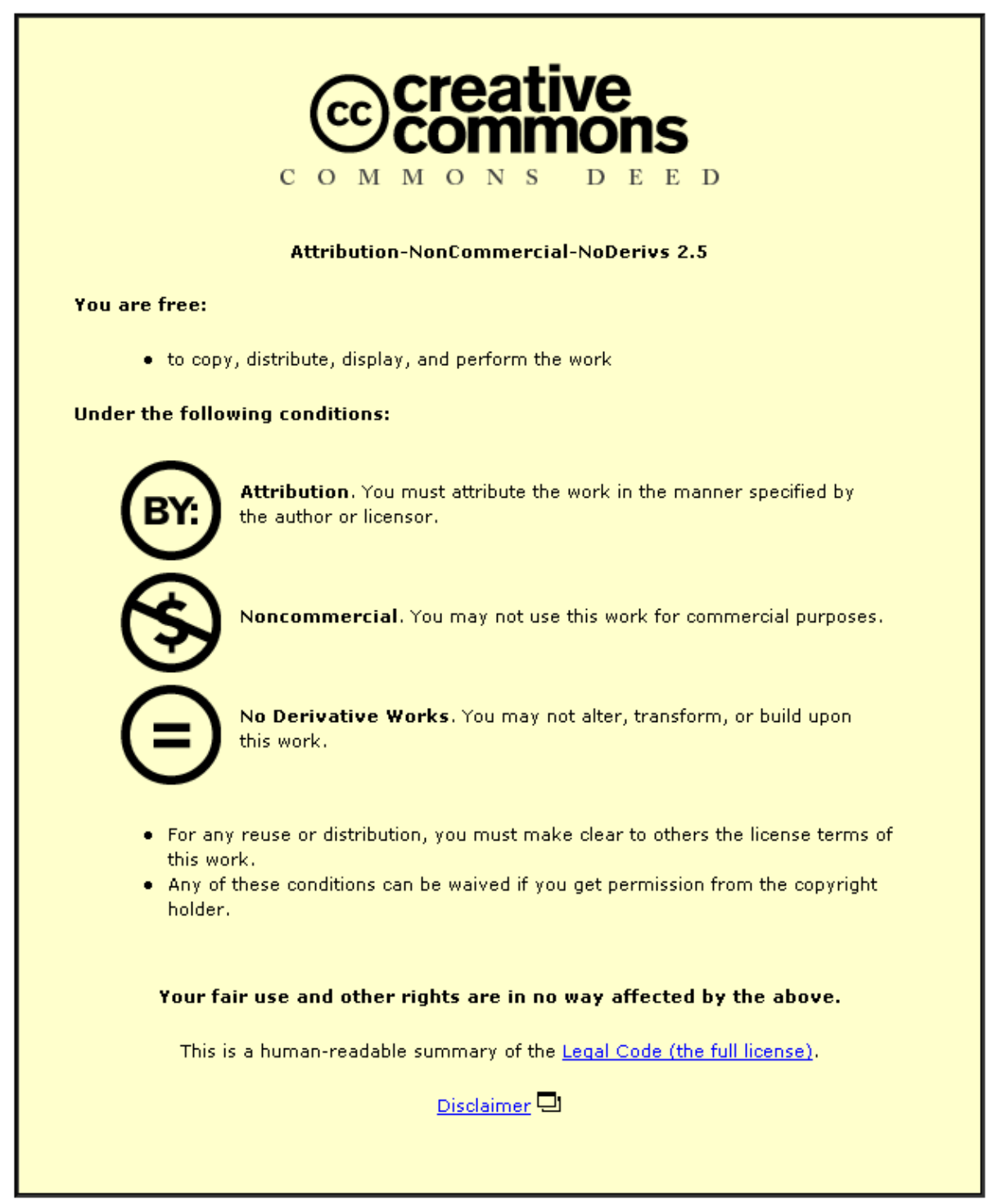

For the full text of this licence, please go to: http://creativecommons.org/licenses/by-nc-nd/2.5/ 


\title{
Venture Capital in Malaysia: \\ The Role of the Government
}

\author{
Grahame Boocock*
}

This article examines the role of venture capital in developing countries, with reference to the development of the industry in Malaysia. The principal issue explored in the paper is whether attempts by the Malaysian Government to promote venture capital have been successful.

*Lecturer in Banking, Loughborough University Business School, Loughborough, UK. This article is based on an empirical study conducted when the author was employed as the British Aerospace Associate Professor at University Utara (North) Malaysia. The author is grateful for the cooperation of the firms interviewed. 


\section{Introduction}

For over twenty five years, Malaysia has prospered. Economic growth, measured by GDP, has averaged over 7\% per annum since independence in 1957. By 1994, despite having a population of only 19 million people, Malaysia had become the world's nineteenth largest trading nation.

Its economic strength was formerly based on commodities such as rubber, timber and palm oil. For a time in the mid-1980s, growth was affected by the global recession and structural weaknesses in the domestic economy. However, industrialisation has accelerated in recent years; the average increase in GDP has been in excess of 8\% per annum between 1988 and 1994. The country is now one of the hubs of the global electronics industry and it also manufactures a wide range of other goods. Commodity-based industries are moving into value-added manufacturing activities such as furniture, food and chemicals.

A series of Five-Year Plans have been implemented. The most recent (the sixth, covering the period 1991-5) committed the government, historically a major employer, to a strategy of growth led by the private sector. An extensive privatisation programme has been set in train, inward foreign investment is being attracted, and capital- and technology-intensive industries are encouraged.

In this environment, small and medium-sized enterprises (SMEs) have the potential to play a crucial role in supporting balanced growth across the economy (Bannock and Albach, 1991). The development of a small firm sector can assist in the transition from developing to developed country; the experience of Japan and other newly industrialised countries in Asia seems to suggest that a modern SME sector is a necessary condition for sustained and accelerated development. The importance of SMEs has been increasingly recognised in Malaysia (Chee, 1992); indeed, the sector began to enjoy positive discrimination relative to large companies by the late 1980s (Fong, 1990). 
One area of particular concern has been the availability of funds for SMEs. Access to finance (rather than its cost) has long been identified as a major problem (Chee, 1986). While the range of funding options available has undoubtedly widened over the past two decades, the financial system remains primarily debt-oriented. High levels of debt are not normally appropriate for companies with a high degree of risk, but with the potential for rapid growth. In these circumstances, venture capital can fill an important gap in the financial intermediation process. Venture fund managers seek out and nurture high growth companies, which are frequently refused finance from conventional sources, hence venture capital can be an important catalyst to entrepreneurship and economic growth (Ray, 1993). Venture capital could therefore assist the development of the SME sector in Malaysia, which in turn is crucial to the continuing prosperity of the economy.

By the summer of 1994, the venture capital industry had been in operation in Malaysia for a decade. Despite its capacity to play a crucial role in economic development, however, the industry has not been subject to independent empirical review. This article attempts to fills that gap. Interviews based on a semi-structured set of questions were conducted with senior officials of 10 venture funds. Only 14 funds are operating in Malaysia; this article therefore represents the views of a substantial majority of the venture capital community.

The article is structured as follows. The next section assesses the role of venture capital in developing countries, describes the development of the industry in Malaysia and sets out the incentives offered by the government. The following section, drawing on the views of survey participants, gives some general information on their investment policies and practices. The impact of government policy is then explored, and the constraints and opportunities facing the sector are summarised. The final section considers the implications of the findings for official attempts to promote venture capital in other developing countries. 


\section{Venture Capital in Malaysia}

The potential role of venture capital

The financial system serving the needs of SMEs in Malaysia is primarily debtoriented and combines both private and public sector financial institutions. In the private sector, the commercial banks and other financial institutions have aggressively sought lending opportunities in the small business sector. The value of credit facilities extended by the core banking system - commercial banks and finance companies - to small scale enterprises had reached RM9.8bn ${ }^{1}$ by the end of 1992 (Bank Negara, 1993). SMEs also have access to funding from a number other sources, including publicly-backed development finance institutions and private leasing and factoring companies. Outstanding credit facilities to small firms from outside the core banking system are thought to be around RM9-10bn (Lin, 1994).

However, SMEs across the globe experience difficulties in raising external funding, especially bank finance. These difficulties stem from a variety of interlinked factors. The risk of failure for SMEs is traditionally higher than that of larger firms, especially in the early years of operation. This problem is compounded by information asymmetries which hinder lenders in their efforts to identify sound borrowers. As a result, it is rarely feasible for lenders to compensate for the risks inherent in an SME lending portfolio by adjusting the interest rate for individual companies (Greenwald, Weiss et al., 1984; Weiss and Stiglitz, 1981). Furthermore, advances to SMEs need to be carefully appraised to ensure that the borrowers use the funds effectively (the moral hazard problem); the costs of the initial assessment, and the ongoing monitoring, are usually very high relative to the amount requested.

Venture capital, by contrast, is typically associated with equity or equity-linked financing instruments. Such investments are unsecured. As a consequence, venture fund managers take a much more direct involvement in the business than

\footnotetext{
${ }^{1} \mathrm{RM}=$ Malaysian Ringgitt. The rate of exchange at that time was approximately RM4 to $£ 1$.
} 
banks and other debt providers. In return, they have the opportunity to share in the success of the companies invested in when the shares are subsequently sold, for example after the investee company achieves a stock market quotation.

In certain circumstances, information asymmetries may also cause difficulties for equity markets (Davis, 1992: 8). In general, however, the substitution of venture capital for debt should help to overcome some of the problems associated with debt and offer a more appropriate method of funding high risk SMEs.

In the early years of its development in the United States, venture capital was closely associated with the early-stage financing of companies dealing with advanced technology. The economic importance of new technology based firms has been recognised; they make a key contribution to the efficiency of research and development, economic growth and employment (Rothwell, 1989). However, high-tech SMEs present financiers with even greater risks than conventional smaller enterprises, because, for example, such firms require high levels of upfront investment, with uncertain market acceptance of their products.

While high tech firms have benefited from a large share of venture funds in developed countries, and such firms remain an important target for fund managers, support for high tech activities represents only one element of the investment funds committed by venture capitalists across the developed world. (In the UK, for example, venture capitalists have acknowledged their limited support for high tech SMEs: Murray, 1994.) Investments are made across a range of commercial situations, from funding pre-production 'seedcorn' projects to financing start-ups, expansions, recoveries and buy-outs.

It is the emergence of a somewhat broader spectrum of investment choices that makes venture capital such an attractive option for policy-makers attempting to tackle the financial problems faced by SMEs in emerging economies (Sagari \& Guidotti, 1991). Venture capital may not, however, be suitable for all developing countries. Investment opportunities may be restricted by poor prospects for economic growth, an economy which stifles entrepreneurial activity, or a lack of divestment avenues (Ibanez, 1989). A survey by the Industrial Finance 
Corporation (IFC, 1986) had already identified Malaysia as having the potential for a thriving venture capital sector (together with cultural and economic environments as varied as Korea, Kenya and Argentina).

The development of the venture capital industry in Malaysia

The first venture fund was established in Malaysia in 1984. Despite the positive comments in the IFC Report noted above, progress was modest until the early 1990s. A number of reasons for growth in the industry can be identified.

On the demand side, the buoyant domestic economy and the availability of government incentives have created opportunities for SMEs to thrive. In addition, an influx of multinationals require the services of local sub-contractors to supply specialised services, parts and components. As a result, the population of SMEs is now estimated at more than 300,000 (New Straits Times, 11 June 1994). Nevertheless, the SME sector remains 'very fragmented and characterised by a lack of product differentiation and appropriate technology' (Bank Negara, 1992). SMEs have gradually become more aware of the benefits of venture capital as an alternative source of finance. Increased awareness may also have 'spilled over' from venture capital activity in Singapore and from the recent growth in Islamic banking, which contains many of the features of venture capital (Boocock and Presley, 1993).

On the supply side, major corporations are increasingly prepared to invest in venture funds on a commercial basis. A significant incentive stemmed from the increased potential for divesting investments, following the formation of a Second Board on the Kuala Lumpur Stock Exchange (KLSE) in 1988. This gave smaller companies the opportunity to earn a public listing. The number of companies quoted on the Second Board by the end of 1993 had reached 84, compared to 413 on the Main Board. Strong economic fundamentals and corporate earnings enabled both stock markets to reach record levels of fund mobilisation and market capitalisation over recent years. However, only a very small number of companies backed by venture capital had actually achieved a listing on either Board by 1994. Nonetheless, the importance of the Second Board for venture 
capitalists should not be underestimated. In all countries where secondary markets exist today, they have followed and not preceded the establishment of a venture capital sector.

Table 1: Venture funds in Malaysia

\begin{tabular}{|c|c|c|c|c|}
\hline \multirow[t]{2}{*}{ Year } & \multirow[t]{2}{*}{$\begin{array}{r}\text { Number of } \\
\text { funds }\end{array}$} & Investment pool & $\begin{array}{l}\text { Outstanding } \\
\text { investments }\end{array}$ & \multirow{2}{*}{$\begin{array}{r}\text { Investments / } \\
\text { Pool } \\
\%\end{array}$} \\
\hline & & (RMm) & (RMm) & \\
\hline 1984 & 1 & 13.8 & $\mathrm{n} / \mathrm{a}$ & $\mathrm{n} / \mathrm{a}$ \\
\hline 1990 & 6 & 92.8 & 33.8 & 36.4 \\
\hline 1991 & 8 & 173.0 & 52.3 & 30.2 \\
\hline 1992 & 13 & 361.0 & 65.0 & 18.0 \\
\hline 1993 & 14 & 384.0 & 124.0 & 32.2 \\
\hline
\end{tabular}

Source: Bank Negara (Central Bank) Annual Reports.

As a result of the interaction of these demand and supply factors, the number of venture funds has increased rapidly over recent years (see Table 1). The figures in Table 1 cover only investments made by funds based in Malaysia. It is known that venture capitalists from outside the country have also made modest investments. Overall, the amounts invested by venture capital companies in Malaysia have not kept pace with the funds raised. However, there was a surge of investment in 1993 (see Table 2 - overleaf). 
Table 2: Annual investment by venture funds in Malaysia

\begin{tabular}{lrrrrr} 
Year & Amount & $\begin{array}{r}\text { Investee } \\
\text { companies } \\
(\text { No.) }\end{array}$ & $\begin{array}{r}\text { Start-up } \\
(\text { RMm })\end{array}$ & $\begin{array}{r}\text { Expansion } \\
(\%)\end{array}$ & $\begin{array}{r}\text { Acquisition/ } \\
\text { buy-outs } \\
(\%)\end{array}$ \\
\hline $1984-9$ & $\mathrm{n} / \mathrm{a}$ & $\mathrm{n} / \mathrm{a}$ & \multicolumn{3}{c}{ 'mostly' later stages } \\
1990 & 21.1 & 8 & \multicolumn{2}{c}{ not available } \\
1991 & 18.1 & 12 & 'bulk' in later stages & \\
1992 & 26.0 & 17 & 51 & 39 & 10 \\
1993 & 68.0 & 43 & 19 & 71 & 10 \\
\hline
\end{tabular}

Source: ibid.

Information on the number and value of investments in each year was only made available from 1990 onwards. The columns towards the right hand side of Table 2 show that the majority of the investments (except for 1992) have been in laterstage (expansion) investments.

\section{Government Incentives}

The Malaysian Government has consistently expressed its desire for the existence of a thriving venture capital sector (Lin, 1994). Growth in this field also has a strong ideological appeal, in line with the move towards privatisation.

Venture capital appears to be strongly equated in official circles with the funding and nurturing of high technology firms. The government has implemented a number of measures to encourage the growth of such firms. For example, the country's first Technology Park was established near Kuala Lumpur in 1988, significant tax incentives are available for high-tech investments and a National Action Plan for Industrial Technology Development was formulated in the sixth Five-Year Plan. In addition, the government has introduced specific incentives which benefit venture funds investing in certain types of companies. 
To qualify for assistance, a venture capital company (VCC) must invest at least $70 \%$ of its fund in 'venture companies' (VCs). (The terminology is somewhat confusing.) VCs are defined by the Ministry of Finance as 'companies involved in high risk ventures or ventures in new technology in relation to a product or activity which the Minister of Finance is satisfied would enhance the economic or technological development of Malaysia'.

It was evident that parts of this definition were open to differing interpretations. More detailed guidelines were therefore issued by the Ministry:

- 'High risk' includes firms which encounter risks over and above those experienced by more traditional SMEs by, for example: incurring high costs, and facing a long payback period, on the initial investment; launching a new product or entering a new market; and receiving little or no government protection against competition.

- 'New technology' is defined as incremental improvements in existing processes and products, and the use of technologies which are new to Malaysia (even if these are technically mature and in common usage elsewhere). Examples of new technology given in the guidelines include: automated manufacturing technologies such as robotics; biotechnology; and renewable energy technology.

Provided that venture funds are prepared to register with the Ministry of Finance for VCC status and submit their investments for prior approval, the incentives available are as follows:

(i) Where a VCC receives gains from the disposal of shares in an investee company, it is exempted from tax for that year of assessment; however, capital gains realised more than 3 years after a KLSE listing will not be exempt. 
(ii) Where a VCC incurs a loss on the disposal of shares or the liquidation of one of its venture companies, it is allowed to set off such losses against other income, in accordance with the formula

Deduction $=E * 1 / 4 C$, where

$E=$ expenses not normally deductible against income

$\mathrm{I}=$ gross income arising from dividends, interest and rent

$\mathrm{C}=$ I plus gains made from the disposal of shares in a VC.

\{This formula results in a tax saving of a maximum of $25 \%$ of the value of expenses which would not normally be allowable for tax purposes.\}

(iii) Where the costs of managing a fund would have to be charged to investors rather than offset against profits, 'permitted expenses' - directors fees, wages and salaries, rent and other expenses - in any year of assessment can be carried forward to the following year.

\section{The Survey Findings}

The sample

By the summer of 1994, after a decade of venture capital in Malaysia, it seemed opportune to review the progress of the industry. Interviews were conducted with senior fund managers in seven major VCCs. The participants controlled 10 funds in total (see Table 3 overleaf).

The information gathered in the interviews therefore represents the opinions of a substantial majority of the venture capital community in Malaysia. The sample funds had raised over RM240m (compared to a total investment pool ${ }^{2}$ in excess of

\footnotetext{
2 The investment pool includes funds available from Perbadanan Usahawan Nasional Berhad (PUNB), a pro-Bumiputera agency with a RM100m fund for investment in specified manufacturing sectors. However, it is questionable whether PUNB's activities can be classed as true venture capital. The equity participation is only temporary in nature and the shares are automatically sold back to the company after a specified period.
} 
RM400m), with investments totalling approximately RM140m (RM205m) in around 62 (approximately 100) companies.

Table 3: Venture funds in survey

\begin{tabular}{|c|c|}
\hline $\begin{array}{l}\text { Venture fund } \\
\text { (major shareholders/affiliates, if not stated in the fund's } \\
\text { name) }\end{array}$ & $\begin{array}{l}\text { Date of } \\
\text { formation }\end{array}$ \\
\hline Citicorp Capital Sdn Bhd & 1991 \\
\hline $\begin{array}{l}\text { B I Walden Ventures Bhd } \\
\text { (Bank Industri, The Walden Group) }\end{array}$ & 1990 \\
\hline B I Walden Ventures Kedua Bhd & 1992 \\
\hline Malaysian Technology Development Corporation (MTDC) & 1992 \\
\hline $\begin{array}{l}\text { Malaysian Technology Ventures One Sdn Bhd } \\
\text { (MTDC and Hambrecht \& Quist) }\end{array}$ & 1993 \\
\hline $\begin{array}{l}\text { Malaysian Ventures Bhd } \\
\text { (Arab-Malaysian Merchant Bank Bhd, } \\
\text { Bank Pembangunan Malaysia Bhd, and major corporates) }\end{array}$ & 1984 \\
\hline $\begin{array}{l}\text { Malaysian Ventures II Bhd } \\
\text { (as above) }\end{array}$ & 1991 \\
\hline $\begin{array}{l}\text { PHB Nomura Jafco Management Sdn Bhd, } \\
\text { (Permodalan Nasional Bhd, Nomura Group) }\end{array}$ & 1991 \\
\hline $\begin{array}{l}\text { Sanyo Pica Asian Ventures Ltd } \\
\text { (Pica (M) Corp, and Sanyo Finance Co (Japan) Ltd) }\end{array}$ & 1986 \\
\hline Southern Bank Venture Capital Corp Sdn Bhd & 1989 \\
\hline
\end{tabular}

The sample included one fund which was wholly foreign-owned, others with foreign equity participation (ranging from $13.3 \%$ to $49.2 \%$ ) and a minority funded solely by Malaysian capital. Apart from financial institutions, the investors in the funds were mainly large private companies or government-controlled bodies. The investors rely upon the fund managers to provide specialised expertise in 
evaluating potential investee companies. This is a critical role, because the financial system in Malaysia is geared towards asset preservation, rather than backing high risk/high yield projects.

Investment policies and practices

A number of questions in the interview programme gathered information on investment policies and practices adopted by the fund managers.

Overall investment policy. In common with venture capitalists elsewhere, the overriding aim is to invest in companies with high growth potential ${ }^{3}$. However, the funds (with one exception) tended to adopt a relatively short-term perspective, backing 'companies looking to go public'. Syndication of deals is rare. The exception is the Malaysian Technology Development Corporation (MTDC), a government-backed body established to support high tech firms. MTDC operates an independent fund and also Malaysian Technology Ventures (MTV), in concert with a major international player, Hambrecht and Quist. MTDC invests in smaller, technology intensive projects, whereas MTV tends to support established firms which will soon be eligible for listing.

Stage of funding cycle. Few funds were willing to invest in start-ups. One established fund manager complained of 'bad experience' with start-ups in the past. Where start-ups had been supported, such companies were usually bringing established products to Malaysia for the first time. Apart from MTDC, which is prepared to back young/start-up companies with seedcorn money, the investments have tended to be in medium-sized companies requiring later-stage finance.

\footnotetext{
${ }^{3}$ Investment policies include: Fund A - any manufacturing or service company with high growth potential; owner-operated; established for minimum of two years; annual sales, minimum RM5m; companies seeking liquidity before going public; Fund B - companies with above-average growth potential, where the fund can add value through working relationships; innovative, proprietary products/services; management with appropriate experience, exceptional drive, integrity and an in-depth knowledge of the particular industry; Fund $\mathrm{C}$ - any high-risk venture in manufacturing or services, which promotes economic or technological development in Malaysia; proven management; high growth; product differentiation; competitive advantage; and sound financial controls.
} 
Number of deals. Most funds had backed fewer than 10 firms, and the average deal size was substantial - close to RM3m. By contrast, MTDC had utilised its own Fund to invest RM19m in a total of 15 companies - a much smaller average deal size.

Type of companies. The bulk of the funds, over $80 \%$, have been directed to the manufacturing sector, especially in the fields of electronics, plastics and ceramics, which are existing areas of strength of the economy. Investment practices seem to differ from the investment policies (as described in Note 3). For example, Malaysian Ventures Bhd, established in 1984, intended to invest in high tech firms. While that Fund has backed some companies operating in the computer and data-base fields, the bulk of its investments have been in more conventional resource-based ventures in, for example, rubber products and furniture. Venture fund managers, apart from those at MTDC, have generally been reluctant to make small investments in high risk sectors.

Progress of investee companies. At this stage in the life of the funds, the most common response was that it was 'too soon to know' or that the investee companies were 'on plan'. However, two funds did admit that a couple of their investments were causing concern.

Exit routes/timescale. The consensus of opinion was that any investment should be realised within 1-5 years, with the funding acting as 'jet fuel' prior to flotation or acquisition by a larger company. The emphasis placed on the availability of a confirmed exit route for an investment suggests that fund managers in Malaysia are more risk-averse than elsewhere (MacMillan et al., 1985). 


\section{The Role of Government}

While it was generally accepted by the interviewees that the government had a genuine desire to encourage the growth of the venture capital industry, concern was expressed on two counts: the incentives currently offered to venture funds, and the impact of the government's efforts to encourage economic participation by the indigenous Malay community. These two factors are discussed below.

\section{Tax incentives}

Participants were asked whether their own Fund had utilised the tax incentives outlined earlier in this article. Some respondents were unaware of their existence. Others had decided not to claim, judging that the stringent requirements to qualify as a VCC rendered the incentives virtually inaccessible.

The system of approving an investment as a qualifying VCC was criticised as cumbersome and uncertain. Currently, approval has to be granted before an investment is completed. This is unworkable, because of the pressure on the fund managers to respond quickly to propositions. Retrospective approval would prevent delay, and would also obviate the need to circulate sensitive commercial ideas around government departments. Only one interviewee had, in fact, applied to the Ministry of Finance for approval of investments 'to test the water'. The outcome was disappointing, as the Ministry failed to respond for over 8 months. It was urged that government officials should become more commercially oriented and less bureaucratic.

In essence, the incentives on offer are not being utilised. What recommendations were put forward as to how this impasse could be resolved?

To make the existing system of incentives more accessible, it was suggested that the qualification threshold for a VCC could be lowered from the present minimum of $70 \%$ of investments in 'high risk' or 'new technology' companies. Prior to the 1994 Finance Act, a VCC had to place all of its funds in such firms. 
The general consensus however, was that, instead of revising the VCC threshold, the definition of a venture company (VC) as a high-risk or new technology firm should be revised. Two reasons were put forward in support of this view. First, it is unrealistic to expect high levels of primary research and development in Malaysia, particularly by SMEs; this is acknowledged in the definition of 'new technology' provided in the official guidelines. (As noted above, Malaysian Ventures Bhd intended to invest in high-tech firms, but discovered that this objective was too ambitious, given the existing state of technology in the country.) The interviewees did not see growth prospects for firms utilising new technology, except for 'possibly semi-conductors' or 'maybe resource-based' activities. Secondly, venture capital could be narrowly perceived by potential clients as financing only high-risk businesses or those undertaking basic research into high technology products. This is clearly not the case in practice. A number of alternative definitions of a VC were proposed, based upon firms offering 'value added' or 'benefits to the country'.

These problems of terminology are not insurmountable. Other countries also have laws specifically defining venture capital companies and their procedures. In South Korea, for example, official guidelines specify that new venture funds should support start-up companies at the expense of more lucrative portfolio investments (Kiernan, 1994). However, the existence of such legislation is usually associated with the availability of attractive tax benefits for the sector.

The perception in Malaysia is that the present package of government incentives is inadequate, even if an acceptable system of defining a VCC or VC could be devised. In Singapore, for example, venture funds are allowed to write off the full capital loss arising from the sale of shares in approved companies against income, the rationale being to encourage investments that would not otherwise be made (for example, seedcorn capital where the return is unlikely to compensate for illiquidity and firm specific risk). The incentive in Singapore is more powerful than its equivalent in Malaysia, namely, the ability to offset losses on the disposal of shares up to a maximum of $25 \%$ of allowable expenses. 
When interviewees were questioned about what additional support they would like to receive from government, changes to the general taxation rules applied to VCCs were often called for.

Across the globe, venture capital companies are organised under the 'everything under one roof' (single tier) or 'fund plus management company' (second tier) approaches (Ibanez, 1989). In the second approach, the venture fund is structured as a limited partnership to which investors contribute their capital. The management of the fund is entrusted to a management company, structured as a general partnership. The limited partnership approach (which operates in, inter alia, the United States, the United Kingdom, Japan and Singapore) is only attractive if the country's tax laws are designed to avoid double taxation on the limited and general partners (Ray, 1993). The fund itself is not normally liable for taxation on its income or chargeable gains, and the limited and general partners should only be taxed when income or capital gains are distributed. This concession takes account of the fact that the venture fund essentially acts in an intermediary role.

In Singapore, it was acknowledged that support for innovation has to be government-led ${ }^{4}$. The Singapore Government recognised that venture capital, by supporting SMEs, could be a powerful mechanism for enabling the transfer of technology to take place. The principal incentive for venture funds is the granting of pioneer status for local venture capital funds, with tax exemption for up to 10 years based on the limited partnership model.

The position in Malaysia is much less clear-cut. Venture funds can structure themselves as investment holding companies, which are exempt from tax on capital gains (except for capital gains realised more than 3 years after a KLSE listing). However, when a venture fund becomes actively engaged in selling its

\footnotetext{
${ }^{4}$ The impetus for the growth of venture capital in Singapore stemmed from the publicly owned Economic Development Board (EDB), which established a S\$100m venture fund in 1986. This was supplemented by the active participation of another government agency, Singapore Technology Ventures. The pool of venture capital funds in Singapore had reached S\$2.6bn by 1993. Investments have been made in companies based in the United States, as well as Singapore, across a wide range of industries including computer hardware, automation, furniture and health care.
} 
shares in investee companies, it is deemed to be an investment trading company for tax purposes. As a consequence, $30 \%$ of profits is paid away in tax. This drain on profits was naturally a source of some resentment among the survey participants; it is difficult to provide the returns necessary to compensate investors for the risk involved, if the venture fund has to carry a tax liability comparable to that of other corporations. A number of interviewees called for the wholesale introduction of the 'Singapore model' of venture capital support. This would probably upset political sensitivities - Malaysia does not want to be seen to be following its neighbour.

\section{Ethno-political policy}

The second element of government policy which exerts a crucial influence on the venture capital sector is the official attempts to promote racial harmony. In essence, the Malaysian Government has attempted to combine its industrial strategy with an ethno-political policy. In response to serious race rioting, the government instituted the 20 year New Economic Policy (NEP) in 1971. The principal objective of the NEP was to secure increased participation by Malays and other indigenous peoples ('Bumiputeras') in the Chinese-dominated economy by raising Bumiputera ownership of assets, including corporate equity, to $30 \%$. The NEP succeeded in raising Bumiputera shareholdings from a base of $2.4 \%$ in 1971 to $20.3 \%$ in 1990 .

The NEP was replaced by the National Development Policy (NDP). Specific targets for the redistribution of wealth were abandoned in the NDP. However, the overall aim of more ethnically balanced growth survived; furthermore, a number of crucial statutes and institutional obligations were not repealed - notably those concerned with the allocation of corporate equity.

The survey participants explained how these requirements were affecting their operations and commented on how the regulations might be circumvented.

Under official guidelines operated by the Ministry of International Trade and Industry (MITI), any company with net assets above RM2.5m is obliged to 
relinquish $30 \%$ of its equity to Bumiputera partners. (The latter include specified financial institutions, co-operatives, individuals or 100\% Bumiputera-owned companies.) If a listing on the KLSE is sought, a minimum of $15 \%$ of the company's equity has to be offered in the Initial Public Offering (IPO) and an additional $30 \%$ is distributed to Bumiputera partners nominated by the MITI (unless the $30 \%$ requirement above has already been satisfied).

The majority of the VCCs are not classed as 'Bumiputera investors'. This has serious implications for these funds, because a non-Bumiputera-owned company seeking expansion finance, with a view to achieving a KLSE listing in the near future, has a positive disincentive to use venture capital. The owners would have to dilute their control by offering shares to the venture fund, and then suffer a further dilution through the 15\% IPO requirement and the additional 30\% allocation for Bumiputeras. Such a company would be better advised to seek an early flotation and negotiate the distribution of equity with MITI beforehand.

Despite the NDP's abandonment of formal targets for Bumiputera participation, the interviewees did not expect that the Malaysian Government would exempt the venture capital community from this fundamental element of its social and economic policy. In this situation, the venture capitalists accept that they will need to persuade non-Bumiputera companies that the drawbacks of giving up some control to the fund (and probably further dilution on listing) are outweighed by the long term benefits of working with them. It is also acknowledged that certain choice deals from the non-Bumiputera community may gravitate towards venture funds nominated as Bumiputera by the MITI (such as PUNB).

A number of VCCs have organised their funds to qualify for Bumiputera status. In 1994, for example, MTDC mobilised another RM100m fund, which satisfies the official requirements for Bumiputera involvement. However, the MTV Fund, which MTDC operates in association with Hambrecht and Quist, can never be classed as Bumiputera because of its foreign associations.

\section{Constraints and Opportunities}


Interviewees were asked to identify the constraints and opportunities facing the industry. The points set out below summarise their opinions. Many of the issues raised in this sub-section are also subject to government influence, either directly or indirectly. The constraints include the following:

(i) There is still a reluctance amongst SMEs to dilute ownership (quite apart from the requirements in respect of Bumiputera shareholdings); this reluctance is exacerbated by the widespread availability of non-bank funding in Malaysia, often at below commercial rates of interest. The search for deals is also highly labour-intensive and, given the lack of management depth in the country, fund managers have to spend more time with investee companies than is the practice in more developed economies. On a more basic level, in dealing with prospective clients, fund managers typically have to waste valuable time in explaining what an injection of venture capital actually entails.

(ii) The venture capitalists accept that their industry has a fairly negative image; most entrepreneurs are adamant that they know what is best for their company. There are few role models in Malaysia which can provide testimony to the fact that venture capital serves the interest of the entrepreneur and not that of the fund.

(iii) Institutional funding for venture capital is presently limited. Interviewees considered that the situation would be improved if Bumiputera institutions could recognise the potential benefits of investing early in SMEs, instead of simply waiting for allocations of shares under the $30 \%$ requirement when a company is listed. Such allocations have, almost invariably, offered risk-free gains when the shares have traded at a premium.

(iv) No culture of private individuals investing in venture funds exists. There is only a limited number of wealthy individuals with an entrepreneurial background, who might be prepared to invest in 
venture funds. In any event, there are no incentives available to encourage such investment (on the lines of the UK' Venture Capital Trusts).

(v) Listing on the Second Board of the KLSE may become more prevalent in future, but there is still a shortage of exit routes for venture capitalists. For example, the Malaysian Companies Act contains restrictions preventing companies from repurchasing their own shares, although it is possible for the venture fund to sell its shares to individual entrepreneurs.

(vi) As discussed earlier, the links between venture capital and high-tech activity in Malaysia are currently very weak. The perception among interviewees was that the supply of investee companies would not increase in the short term.

(vii) The growth of venture capital in other countries has been associated with the emergence of management buy-outs, and variations such leveraged buy-outs and management buy-ins ${ }^{5}$, as a feature of economic restructuring. Buy-outs usually arise from the sale of an independent company, through divestment by a major conglomerate, or from the privatisation of state-owned bodies. In the UK, for example, buy-outs have accounted for over $60 \%$ of the funds invested by the venture capital community over recent years (BVCA, 1994). See overleaf for more on buy-outs in Malaysia.

(viii) A number of fund managers commented on the fact that they have funds at their disposal, but they are experiencing problems in finding sufficient investment opportunities.

While the above points do not appear encouraging, it has to be stressed that the majority of participants in the survey were very positive about the prospects for their industry. The funds have made a long-term commitment to a presence in Malaysia. 
[Buy-out activity in Malaysia has been very modest to date, mainly linked to the privatisation of government utilities. The survey participants did not see immediate prospects for growth, for two reasons:

Culture. The majority of independent companies and private sector conglomerates have been Chinese-controlled and subject to tight family controls. As a race, the Chinese have traditionally sought to retain control within the family network. The prevailing culture is unlikely to change, although the next generation of managers may not be prepared to work 16-18 hours a day and insist upon total control of their businesses. With a very different lifestyle, the incoming managers may be more outward-looking, and hence prepared to entertain outside investors via venture capital or management buy-outs. One dissenting view stated that seven consecutive years of high growth had put paid to any divestment. If and when there is an economic downturn, cash-hungry conglomerates, irrespective of their ownership, would be eager to sell subsidiaries.

Legal. The Malaysian legal system is not amenable to the development of buyout activity. For example, it is not permitted to pledge the assets of the target company to secure the debt raised to fund the deal. These restrictions can be overcome, but financiers will typically have to rely upon entrepreneurs taking personal responsibility for repayment of the debt.]

Opportunities for the industry were seen in the following areas:

(i) First and foremost, the sustained growth of the economy is generating potential investee companies for venture funds. A number of interviewees pointed to the emergence of a new generation of locally-owned companies in the manufacturing sector. Such companies have the ability to expand rapidly and earn annual profits of RM2-3m within five years, a level of progress which should enable them to achieve the minimum performance criteria for a Second Board listing.

\footnotetext{
${ }^{5}$ All such deals are hereafter referred to as 'buy-outs'.
} 
(ii) Despite the fact that many Malaysian managers remain salarydriven, and reluctant to leave secure employment for risky independence, a culture of entrepreneurship is developing. Individuals with expertise, experience and a network of contacts are increasingly willing to set up in business on their own.

(iii) The inflow of foreign investment has enabled local companies to operate as sub-contractors; these SMEs have then expanded their customer base and achieved rapid growth. A good example is the air freight sector. This trend is reinforced by government-sponsored vendor development programmes aimed at increasing import substitution. SMEs (mainly Bumiputeras) receive favourable treatment in the awarding of contracts.

(iv) Despite the general thrust of the comments in point (viii) above, there was general consensus that buy-outs could (over time) play a more prominent role in the portfolio of Malaysian venture funds. The Malaysian Government is actively pursuing its privatisation policy and opportunities for buy-outs should arise across a range of industrial sectors. In addition, there are some indications that divestment policies may increasingly be pursued by foreigncontrolled companies. In July 1994, ICI Malaysia divested its 50.1\% stake in the Chemical Company of Malaysia to a management team in a complex RM206m deal. This de-merger did not involve venture capital, but it may be followed by others where venture funding could be utilised. On a similar theme, many multinationals based in Malaysia have established wholly-owned subsidiaries to supply their core businesses (rather than use local sub-contractors). Over time, they may be prepared to divest these subsidiaries to local management teams via buy-outs.

\section{Implications for other developing countries}

Based on discussions with prominent members of the venture capital community in Malaysia, this article has reviewed the development of the sector over the first 
decade of its existence. The venture capital investment pool currently stands at over RM400m, although this has to be set alongside the approximately RM20bn credit facilities granted to SMEs by other private and public sector sources. The fund managers' current focus of activity is the funding of later-stage investments. The provision of seedcorn capital to start-ups is rare, as is the funding of high-tech activities. The Malaysian Government has been (and remains) very keen to encourage the growth of the sector. The belief is that a thriving venture capital sector can help to maintain the remarkable growth record achieved by the Malaysian economy over recent years and also assist the move towards more balanced growth by assisting the development of SMEs.

In the light of the survey findings, the principal conclusion of this article has to be that the Malaysian Government's attempts to promote venture capital have not been a success. Within this broad conclusion, a number of more specific (often interlinked) lessons can be drawn for other developing countries. These are set out below.

The incentives offered by government need to form an integrated package. In the case of Malaysia, it is difficult to ascertain a consistent policy in response to the following questions: What exactly is the official definition of a venture capital company (VCC) or venture company (VC), and how should these terms be interpreted? And what kind of tax and financial incentives should it enjoy? The system of qualifying as a VCC was seen to be virtually unworkable. Moreover, the present package of government incentives has not been sufficiently appealing either to attract venture funds to register as a VCC or to influence their investment decisions.

The general tax regime must be designed to encourage private sector finance into venture funds, whether from savings by individuals, large local companies, multinationals, domestic financial institutions or offshore venture capital funds. The limited partnership model has been widely adopted across the world.

Even if the general tax regime is favourable, further action by government will be required to encourage venture funds to invest in new technology. For example: 
specific incentives could be offered, allowing venture funds to write off losses arising from high-tech investments; another approach is to encourage publicly backed funds to support high-risk projects, perhaps alongside private sector funds. The latter approach is found in the operation of the Malaysian Technological Development Corporation, which is adopting a different investment philosophy from that of the other funds, by making smaller, higher-risk investments. This is tangible evidence of the government's commitment, but MTDC has only a limited budget and managerial resources at its disposal.

The theme of an integrated package has to be emphasised again. As Ray (1993) suggests: 'the venture capital sector can only succeed as a catalyst for the growth of high tech firms if it forms an integral component of an indigenous technological infrastructure that includes, inter alia: concentrations of skilled labour; substantial public R\&D expenditure; and access to big domestic or international markets'.

Turning to more specific points:

a) Attempts to combine financial and social policies can lead to market distortions. In Malaysia, it was evident that the country needs the expertise provided by foreign-backed funds, yet the Bumiputera discrimination in shareholding requirements favours a minority of locally based funds at the expense of those with international links.

b) Market inefficiencies can result from an absence of effective information networks. Venture capitalists in Malaysia currently conduct a labourintensive search for deals. They (and fund managers elsewhere) would benefit from the creation of information networks to facilitate the connection of SMEs with potential investors. Similarly, SMEs need to be educated as to the advantages which venture capitalists can bring to investee companies.

c) Venture capitalist activity is very dependent on a legal framework which allows funds to utilise a range of divestment opportunities for their shares in investee companies. Fund managers in Malaysia welcome the advent of a 
'Junior Stock Market', but suffer from an inability of companies to repurchase their own shares.

d) On similar lines, management buy-outs of all kinds are an emerging worldwide phenomenon. They often rely on venture funding as part of an appropriate financial package. An important pre-requisite is a legal framework which allows the assets of the bought-out entity to be used as security for any debt commitments.

Finally, while factors such as the availability of tax incentives and divestment avenues are important, governments have a crucial role to play in creating a climate in which entrepreneurs and private enterprise are encouraged. This factor was seen as critical by Malaysian venture capitalists when they predicted a prosperous future for their industry.

\section{References}

Bank Negara Malaysia. Various Annual Reports. Kuala Lumpur (various).

Bannock, G. and Albach, H. (1991) Small Business Policy in Europe. London: Anglo German Foundation.

Boocock, J. G. and Presley, J. R. (1993) 'Equity Capital for Small and Mediumsized Enterprises in Malaysia: Venture Capital or Islamic Finance?', Managerial Finance 19(7): 82-95.

BVCA - British Venture Capital Association (1994) Report on Investment Activity. London: BVCA

Chee, Peng Lim (1986) 'Study and Evaluation of Existing Fiscal and Financial Policies and Support for Small and Medium Businesses in Malaysia', in Kenneth James and Narongchai Akranasee (eds), Small and Medium Business 
Improvement in the Asean Region - Financial Factors. Kuala Lumpur: Institute of Southeast Asian Studies, Field Report Series No 16.

Chee, Peng Lim (1992) 'Potential and Problems of SMIs', in Kim Seung Jin and Suh Jang-Won (eds), Co-operation in Small and Medium-scale Industries in ASEAN. Kuala Lumpur: Asian and Pacific Development Centre.

Davis, E. P. (1992) Debt, Financial Fragility and Systemic Risk. Oxford: Clarendon Press.

Fong, Chan Onn (1990) 'Small and Medium-Sized Industries in Malaysia:

Economic Efficiency and Entrepreneurship', Developing Economies, XXVIII 2: 152-79.

Greenwald, B., Weiss, A. and Stiglitz, J.E. (1984) 'Informational Imperfections in Capital Markets and Macro-economic Fluctuations', American Economic Review 74: $174-200$.

Ibanez, F. (1989) 'Venture Capital and Entrepreneurial Development', World Development Report Background Paper No. 53. Washington, DC: World Bank.

Industrial Finance Corporation (IFC) (1986) 'Venture Capital Activities in Selected Countries - Another Look'. Washington, DC: World Bank, Capital Markets Department.

Kiernan, T. (1994) 'Korea: A Crowded Welcome for Venture Capitalists', Institutional Investor, 28(6): 25.

Lin, See-Yan (1994) 'The Financing of Small Scale Enterprises in Malaysia', MCA Conference Proceedings, Kuala Lumpur, 10 April, (unpublished).

MacMillan, I. C., Siegel, R. and Subba Narasimha, P. N. (1985) 'Criteria Used By Venture Capitalists to Evaluate New Venture Proposals', Journal of Business Venturing 1: 119-128. 
Murray, G. (1994) 'The Second Equity Gap: Exit Problems for Seed and EarlyStage Venture Capitalists and their Investee Companies', International Small Business Journal 12(4).

Ray, D. M. (1993) 'Pioneering Venture Capital in Developing Economies: Strategic Implications for Southeast Asia', Journal of International Business and Entrepreneurship 2 (1): 23-63.

Rothwell, R. (1989) 'Small Firms, Innovation and Industrial Change', Small Business Economics 1: 51-64.

Sagari, S. B. and Guidotti, G. (1991) 'Venture Capital Operations', World Bank Working Paper No 540. Washington, DC: World Bank.

Weiss, A. and Stiglitz, J. E. (1981) 'Credit Rationing in Markets with Imperfect Information', American Economic Review 71: 393-410. 